\title{
Cathodic Cage Nitriding of AISI 409 Ferritic Stainless Steel with the Addition of $\mathrm{CH}_{4}$
}

\author{
Rômulo Ribeiro Magalhães de Sousa ${ }^{a *}$, Francisco Odolberto de Araújo ${ }^{b}$, José Alzamir Pereira da Costac,

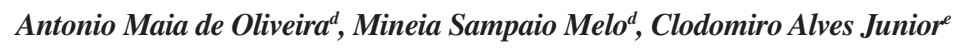 \\ ${ }^{a}$ Departamento de Mecânica, Instituto Federal de Educação, Ciência e Tecnologia do Piauí - IFPI, \\ Praça da Liberdade, 1597, CEP 64000-040, Teresina, PI, Brazil \\ ${ }^{b}$ Departamento de Ciências Exatas e Naturais, Universidade Federal Rural do Semi-Árido - UFERSA, \\ Av. Francisco Mota, 572, Bairro Costa e Silva, Mossoró, RN, Brazil \\ ${ }^{c}$ Departamento de Física, Universidade do Estado do Rio Grande do Norte - UERN, \\ Campus Universitário Central, Setor II, BR 110, Km 48, Rua Prof. Antônio Campos, Costa e Silva, \\ CEP 59610-090, Mossoró, RN, Brazil \\ ${ }^{d}$ Centro Federal de Educação Tecnológica do Maranhão, \\ Av. dos Curiós, sn, Vila Esperança, CP 433, CEP 65095-460, São Luiz, MA, Brazil \\ ${ }^{e}$ Labplasma, Departamento de Física, Universidade Federal do Rio Grande do Norte - UFRN, \\ Campus Universitário, CEP 59072-970, Natal, RN, Brazil
}

Received: July 27, 2011; Revised: January 23, 2012

\begin{abstract}
AISI 409 ferritic stainless steel samples were nitrided using the cathodic cage plasma nitriding technique $(\mathrm{CCPN})$, with the addition of methane to reduce chromium precipitation, increase hardness and wear resistance and reduce the presence of nitrides when compared to plasma carbonitriding. Microhardness profiles and X-Ray analysis confirm the formation of a very hard layer containing mainly $\varepsilon-\mathrm{Fe}_{3} \mathrm{~N}$ and expanded ferrite phases.
\end{abstract}

Keywords: cathodic cage, plasma carburizing, ferritic stainless steel

\section{Introduction}

Stainless steel is widely used in engineering due to its high corrosion resistance, despite its low wear resistance and hardness. However, the two latter properties can be improved significantly through ionic nitriding ${ }^{1,2}$. It is well known that nitriding ustenitic stainless steel at temperatures above $723 \mathrm{~K}$ produces high hardness and wear resistance, but corrosion resistance decreases substantially due to chromium nitride precipitation, resulting in the reduction of chromium in the matrix. When nitriding is carried out at temperatures below $723 \mathrm{~K}$ it produces a supersaturated solid solution of nitrogen called "S phase" or expanded austenite, with high hardness and wear resistance allied to excellent corrosion resistance ${ }^{3,4}$. Nitriding produces a very hard and thin layer, while cementation produces a thick layer that is less hard. The precipitation of chromium nitrite can be inhibited by the addition of small amounts of $\mathrm{CH}_{4}$. The addition of methane results in a hybrid process which produces a thick double layer, the inner layer being supersaturated by carbon and the outer one by nitrogen, leading to high surface hardness ${ }^{5-7}$.

Due to their low hardness, ferritic stainless steels are not normally used in conditions that require wear resistance. However, wear-resistant materials can be obtained either by reinforcing the soft phases with harder phases or by surfacehardening processes. Plasma nitriding stands out among

*e-mail: romulorms@gmail.com surface-hardening processes because of its effectiveness, relatively low cost and the fact that it is non-polluting. Plasma nitriding can be described as a thermochemical method that introduces atomic nitrogen into the material and allows for the deposition of substrate element nitrides. Nitriding of a material depends on the proper correlation between the dominant mechanisms, the system's treatment parameters and the chemical composition of the substrate ${ }^{8-10}$. The resulting layer can be subdivided into a composite layer - consisting mainly of $\varepsilon-\left(\mathrm{Fe}_{2-3} \mathrm{~N}\right)$ and/or $\gamma^{\prime}-\left(\mathrm{Fe}_{4} \mathrm{~N}\right)$ phases, which are responsible for the material's good tribological and anticorrosive properties - and a diffusion zone where the nitrogen is dissolved interstitially in the matrix, leading to high wear resistance ${ }^{10}$.

Nitrided ferritic stainless steels are harder and more wear resistant than austenitic steels. It is well known that plasma nitriding significantly improves the surface properties of austenitic steels; however, little research has focused on the nitriding of ferritic stainless steels ${ }^{11}$.

Ferritic stainless steel has long time been used in metallurgical applications due to its lower cost when compared to austenitic steel, as well as its good corrosion resistance. Ferritic stainless steel is weldable, magnetic, highly formable, and highly corrosion resistant under stress and at high temperatures. It is used in the manufacture of nitric acid storage tanks, automobile accessories, domestic utensils, coins, elevator coatings and refrigerated cabinets ${ }^{12}$. 
In this study, we use the same plasma nitriding reactor, but with a modified experimental arrangement illustrated in Figure 1, called a cathodic cage ${ }^{5,13-15}$, whose principle of operation is based on the hollow-cathode effect in the walls of the all holes.

\section{Materials and Methods}

The material used in this study was AISI 409 ferritic stainless steel, whose elemental atomic compositions are presented in Table 1.
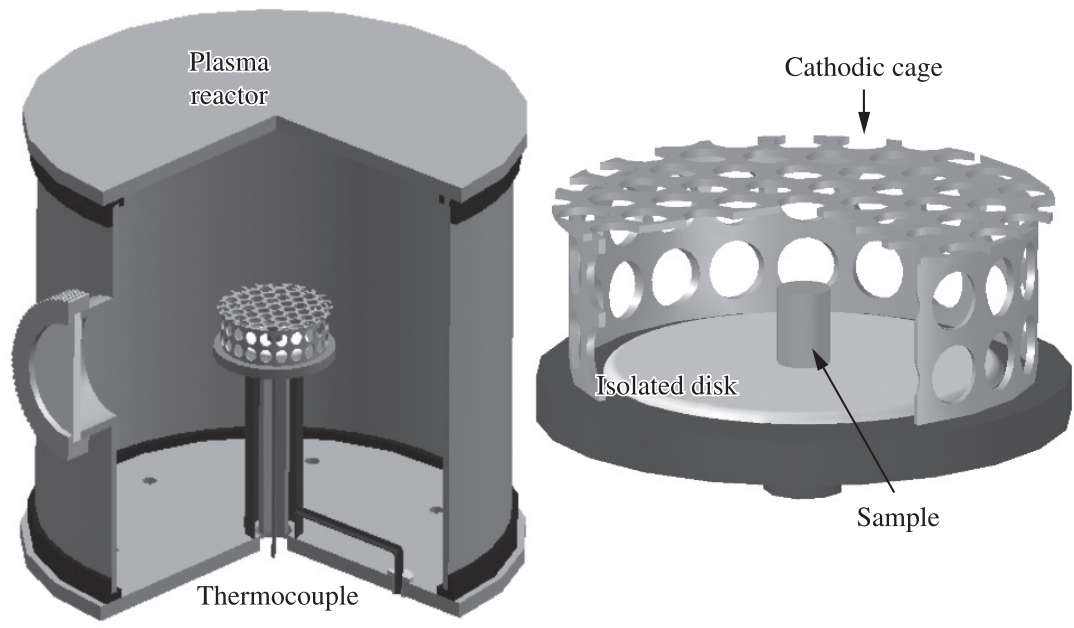

Figure 1. Diagram of the nitriding reactor and view of the cathodic cage containing a sample.

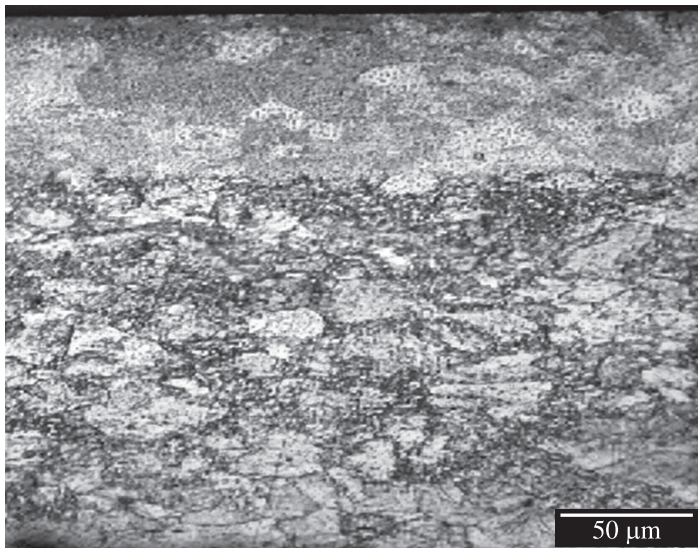

(a)

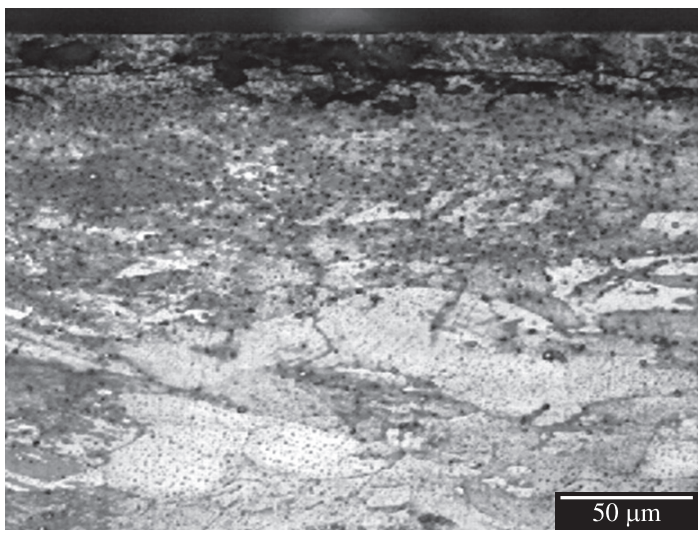

(c)

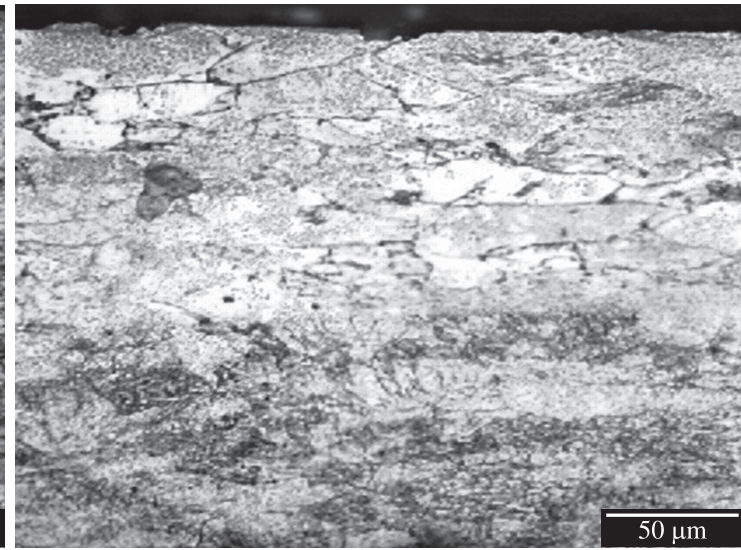

(b)

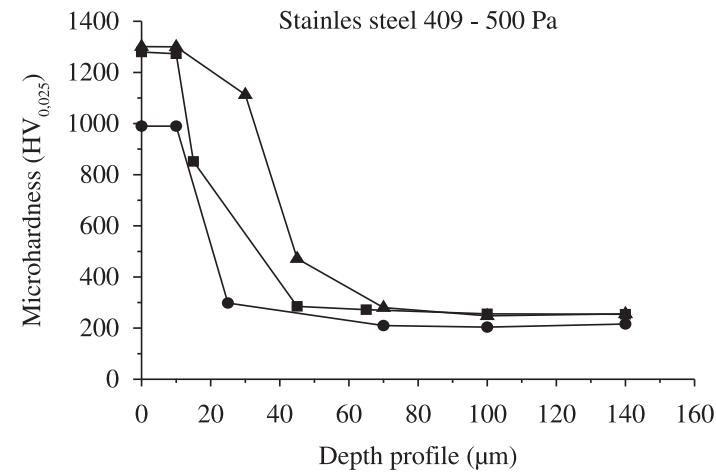

$\multimap 673 \mathrm{~K} \longrightarrow 723 \mathrm{~K} \smile 773 \mathrm{~K}$

(d)

Figure 2. Micrographs of AISI 409 steel nitrided by the cathodic cage technique, with the addition of $\mathrm{CH}_{4}$, for 5 hours under a pressure of $500 \mathrm{~Pa}$ at: a) 673 ; b) 723 ; c) $773 \mathrm{~K}$; and d) microhardness profile. 
Samples of previously solubilized AISI 409 ferritic stainless steel were machined into cylindrical shapes, sandpapered with 320, 400, 600 and 1200 grit sandpaper, and polished with 1 and $0.3 \mu \mathrm{m}$ diamond paste using a felt disc. They were then cleaned ultrasonically in an acetone bath and placed in the nitriding chamber.

The nitriding system consisted of a cylindrical stainless steel vacuum chamber $(40 \mathrm{~cm}$ in diameter and $40 \mathrm{~cm}$ in height) equipped with an evacuation system, with gas flux controlled by a mass flow controller, and a power supply (maximum voltage of $1500 \mathrm{~V}$, maximum electrical current of $2 \mathrm{~A}$ ). This system is similar to the conventional plasma nitriding arrangement, but with the addition of a cathodic cage made of stainless steel plate 316 , with dimensions of $0.8 \mathrm{~mm}$ thickness, $112 \mathrm{~mm}$ diameter, $25 \mathrm{~mm}$ height and $8 \mathrm{~mm}$ diameter holes distributed uniformly, with a distance

Table 1. Elemental composition of AISI 409 ferritic stainless steel (at. \%).

\begin{tabular}{cccccccccc}
\hline & $\begin{array}{c}\mathrm{C} \\
(\boldsymbol{\%})\end{array}$ & $\begin{array}{c}\mathrm{Cr} \\
(\boldsymbol{\%})\end{array}$ & $\begin{array}{c}\mathrm{Ni} \\
(\boldsymbol{\%})\end{array}$ & $\begin{array}{c}\mathrm{Mo} \\
(\boldsymbol{\%})\end{array}$ & $\begin{array}{c}\mathrm{Mn} \\
(\boldsymbol{\%})\end{array}$ & $\begin{array}{c}\mathrm{Si} \\
(\boldsymbol{\%})\end{array}$ & $\begin{array}{c}\mathrm{N} \\
(\boldsymbol{\%})\end{array}$ & $\begin{array}{c}\mathrm{Cu} \\
(\boldsymbol{\%})\end{array}$ & $\begin{array}{c}\mathrm{Fe} \\
(\boldsymbol{\%})\end{array}$ \\
\hline 409 & 0.030 & 11.25 & 0.06 & 0.11 & 0.74 & 0.49 & - & - & Balance \\
\hline
\end{tabular}

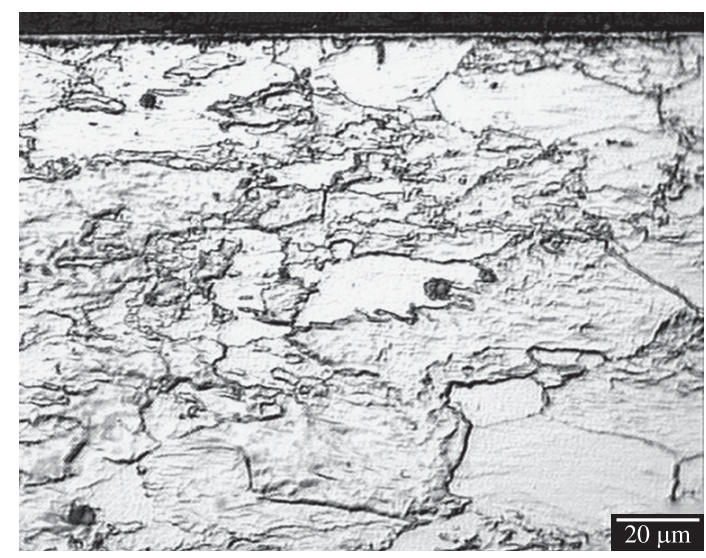

(a)

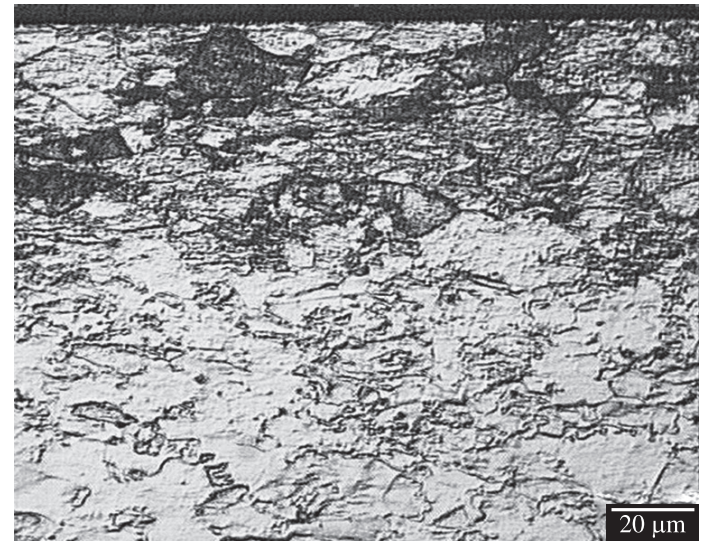

(c) of $9.2 \mathrm{~mm}$ between holes. The plasma was formed in the cathodic cage, i.e., on the negatively loaded workpiece instead of the sample's surface ${ }^{13}$.

The samples were pretreated with hydrogen plasma for 30 minutes at $573 \mathrm{~K}$. The treatment conditions were as follows: 5 hours of cathodic cage nitriding using a $95 \% \mathrm{~N}_{2}-5 \%$ $\mathrm{CH}_{4}$ mixture, and 10 hours of conventional plasma carburizing using a $78 \% \mathrm{H}_{2}-20 \% \mathrm{~N}_{2}-2 \% \mathrm{CH}_{4}$ mixture. The two processes were performed at 673,723 , and $773 \mathrm{~K}$. The $20 \mathrm{sccm}$ flow was adjusted by a controller. The treatment was performed under a pressure of $500 \mathrm{~Pa}$, which was measured with a manually adjusted Barocel capacitance manometer. After nitriding and carbonitriding, the samples were annealed, polished and etched with Beraha II reagent. The samples were analyzed by X-ray diffraction (Shimadzu, XRD-6000, operating at $40 \mathrm{KV}$ ) using $\mathrm{CuK}$ lines and a wavelength of $0.154 \mathrm{~nm}$. The morphology and thickness of the nitrided layer were examined by optical microscopy, and the layer's microhardness profile was determined to confirm its thickness and uniformity.

\section{Results and Discussion}

Figures 2a,b,c show optical micrographs, while Figure $2 \mathrm{~d}$ shows the measured microhardness of the AISI

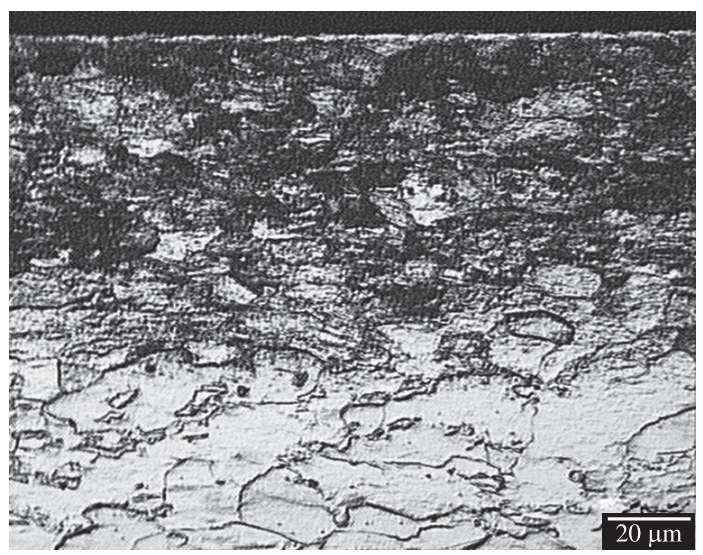

(b)

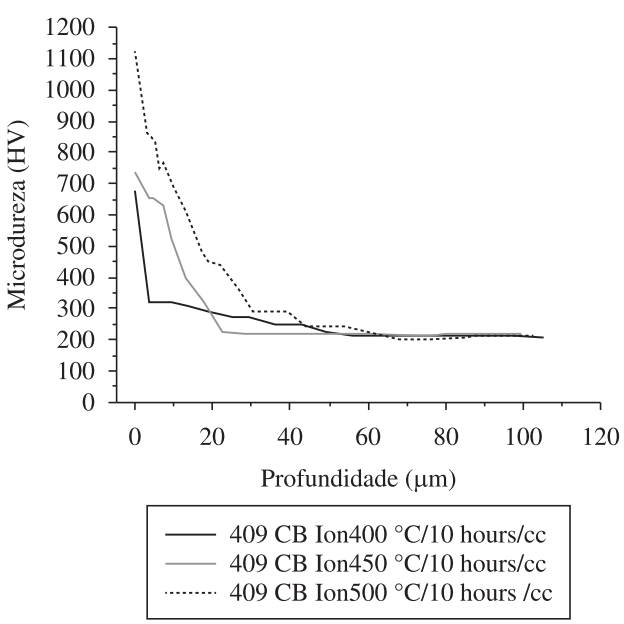

(d)

Figure 3. Optical micrographs and microhardness curves of AISI 409 steel plasma carbonitrided for 10 hours under a pressure of $500 \mathrm{~Pa}$ at: a) 673 ; b) 723 ; c) 773 ; and d) microhardness profile. 
409 steel nitrided by the cathodic cage technique with the addition of methane.

The samples nitrided by the cathodic cage technique and by conventional plasma carbonitriding presented a thin composite layer on the ferritic matrix, as shown in Figures 2 and 3, as well as a much thicker diffused layer which varied directly as a function of the treatment temperature. The layer obtained by cathodic cage nitriding with the addition of methane was much thicker than the one obtained by carbonitriding, for samples with the same period of treatment. Figures 3a,b,c show optical micrographs, while Figure $3 \mathrm{~d}$ shows the measured microhardness of plasma carbonitrided AISI 409 steel. Small amounts of methane were found to prevent the precipitation of chromium nitride, stabilizing the expanded ferrite or $\alpha_{\mathrm{N}}$ phase, and thus increasing the material's corrosion resistance ${ }^{7}$. However, the microhardness decreased with the depht, as can be seen in the curves of the graphs in Figures $2 \mathrm{~d}$ and $3 \mathrm{~d}$, although this decrease occurred more gradually in the samples nitrided in the cathodic cage than in those carbonitrided conventionally, which presented an abrupt drop in microhardness.

Table 2 lists the values of microhardness and composite layer thickness. Cathodic cage nitriding at $673 \mathrm{~K}$ did not cause the formation of a composite layer. Hence, the increase in microhardness of this sample was attributed to the formation of a diffusion zone. The dissimilar nitrogen and carbon diffusion rates were attributed to the different bond energies of these elements. Chromium and nitrogen have a

Table 2. Microhardness and thickness of the composite layer of samples nitrided under different conditions.

\begin{tabular}{ccccc}
\hline & Time (hours) & Temperature $(\mathbf{K})$ & Microhardness $(\mathbf{H V})$ & Thickness of composite layer $(\boldsymbol{\mu m})$ \\
\hline Cathodic cage & 5 & 673 & 1273 & - \\
nitriding & 5 & 723 & 1000 & 26 \\
& 5 & 773 & 1329 & 46 \\
Plasma & 10 & 673 & 700 & 79 \\
carburizing & 10 & 723 & 1150 & 31 \\
& 10 & 773 & & 55 \\
\hline
\end{tabular}
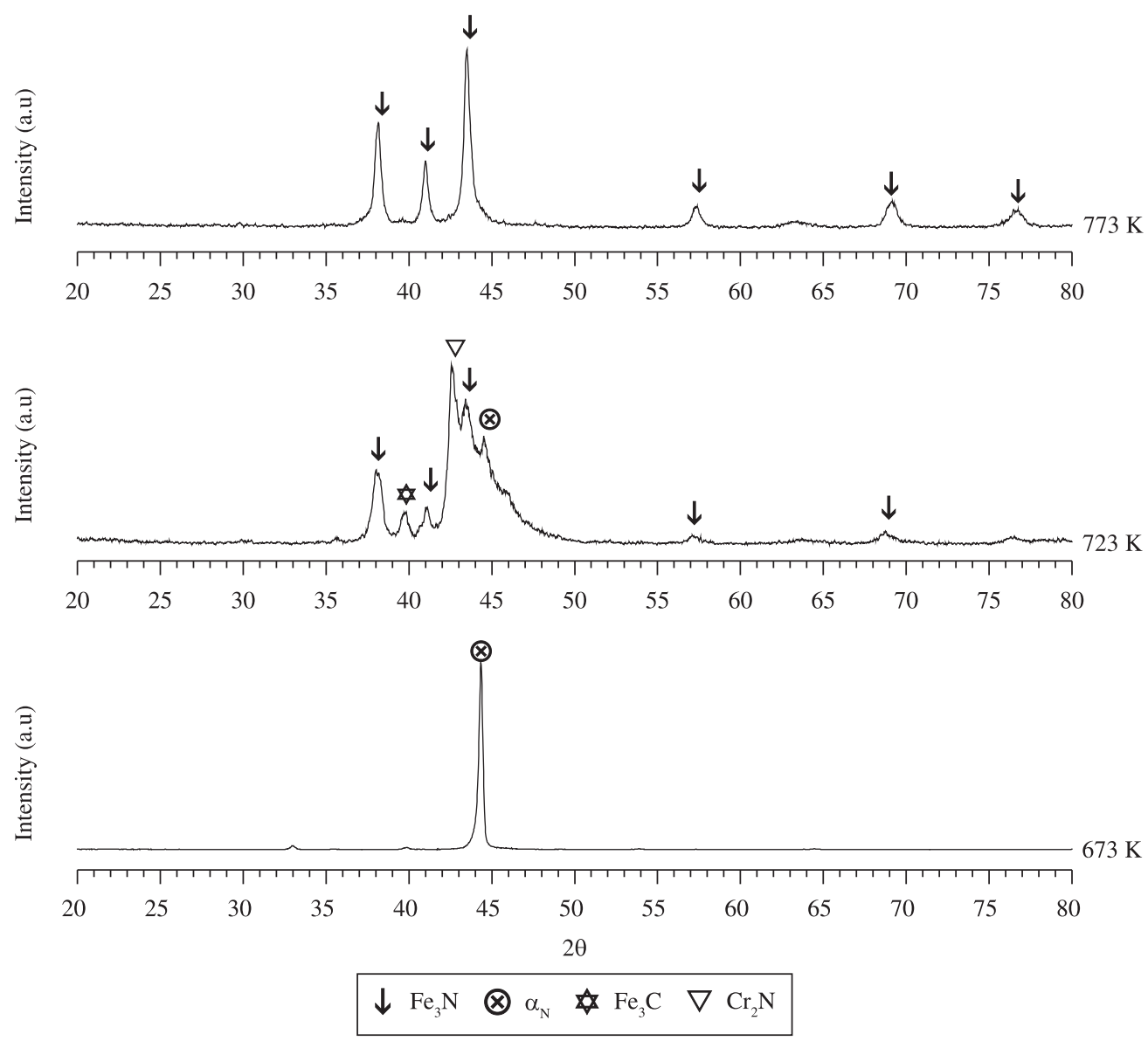

Figure 4. X-ray diffractograms of samples nitrided by the cathodic cage technique, with the addition of $\mathrm{CH}_{4}$, under a pressure of $500 \mathrm{~Pa}$ at 673,723 and $773 \mathrm{~K}$. 

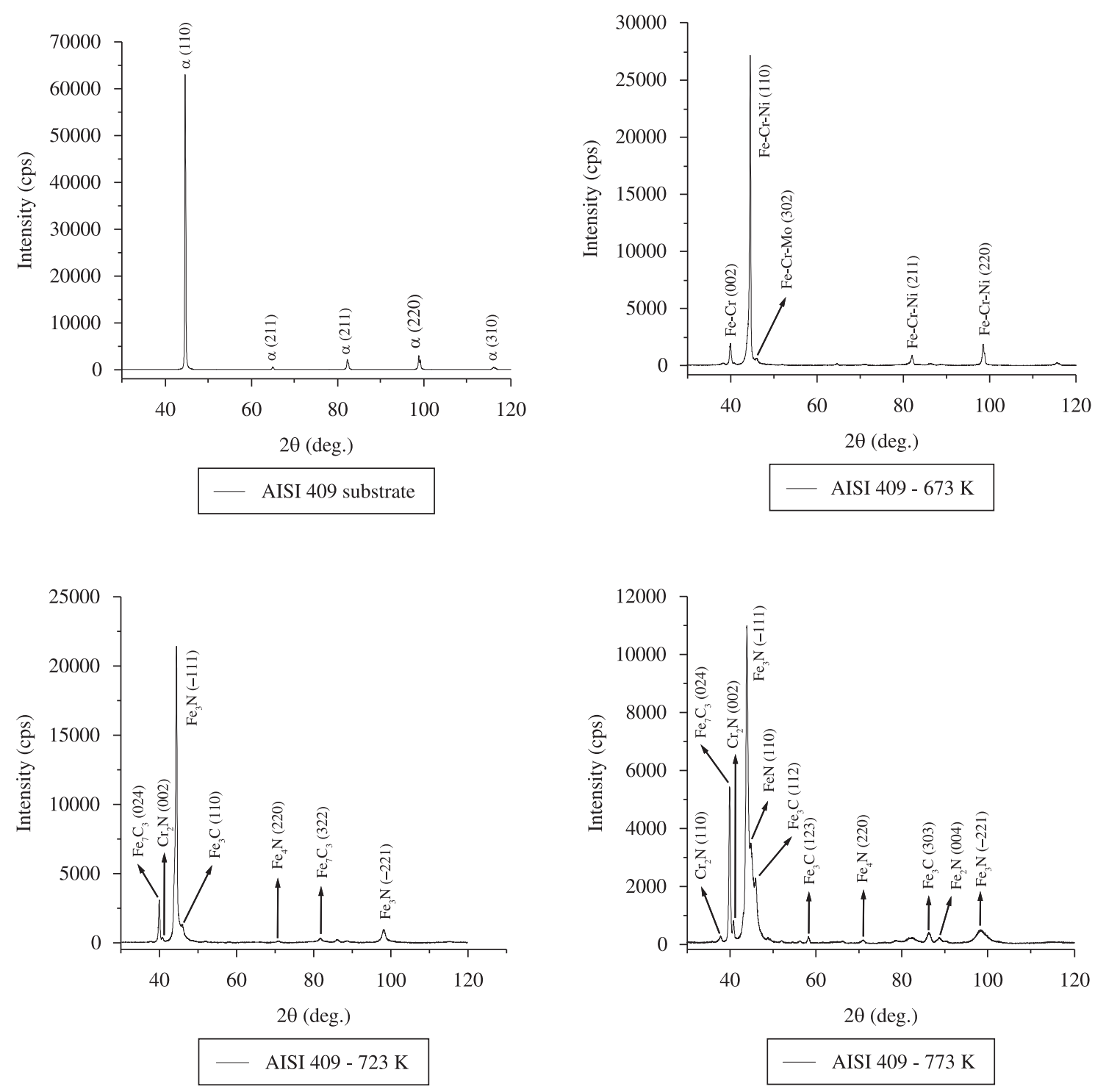

Figure 5. X-ray diffractograms of samples carbonitrided under a pressure of $500 \mathrm{~Pa}$ at 673,723 and $773 \mathrm{~K}$.

strong electronic affinity and easily bond to each other. On the other hand, carbon can diffuse freely through the surface, while nitrogen is more likely to bind to chromium (which will hinder the diffusion of nitrogen $)^{16}$. The values presented here confirm the greater microhardness and thinner layer of the samples treated by cathodic cage nitriding than those of the carbonitrided samples.

In Figure 4, the X-ray diffractograms of the samples nitrided in the cathodic cage with added methane indicate the formation iron nitride, chromium nitride, iron carbide and expanded ferrite, $\alpha_{\mathrm{N}}$ a term used for comparison to expanded austenite, which is due to expansion of the crystalline network. The presence of iron carbide is due to the higher carbon content in ferritic stainless steel than in austenitic steel. Expanded ferrite is responsible for the high hardness of nitrided ferritic steel. Note, in Figure 4, that the peak intensity of the expanded ferrite decreases with increasing temperature, similar to what occurs with expanded austenite in austenitic stainless steel ${ }^{17}$. Precipitation of chromium nitride begins starting from $723 \mathrm{~K}$, when the peak intensity of expanded ferrite decreases. The presence of chromium nitride is less intense in plasma nitriding without the addition of methane, as well as in plasma carbonitriding.

Figure 5 compares diffractograms of AISI 409 steel samples plasma carbonitrided at 673, 723 and $773 \mathrm{~K}$ against the diffractogram of a non-treated sample. Note the greater presence of chromium nitride and the predominance carbides in comparison to the material subjected to cathodic cage nitriding. This finding confirms that cathodic cage nitriding with the addition of small amounts of methane inhibits the precipitation of chromium nitride, thus reducing the loss of corrosion resistance as the nitriding temperature increases.

\section{Conclusions}

The addition of small amounts of methane to the nitriding atmosphere during cathodic cage plasma nitriding 
produces notable changes in the properties of ferritic stainless steel. This nitriding method produces thinner layers that are harder than those obtained by conventional plasma carbonitriding. Moreover, when compared to conventional plasma carbonitriding, cathodic cage nitriding with methane

\section{References}

1. Menthe E and Rie K-T. Plasma nitriding and plasma nitrocarburizing of electroplated hard chromium to increase the wear and the corrosion properties. Surface Coatings Technology. 1999; 199C:116-119.

2. Cheng Z, Li CX, Dong H and Bell T. Low temperature plasma nitrocarburising of AISI 316 austenitic stainless steel. Surface and Coatings Technology. 2005; 191:195-200. http://dx.doi. org/10.1016/j.surfcoat.2004.03.004

3. Menthe E, Bulak A, Olfe J, Zimmermann A and Rie K-T. Improvement of the mechanical properties of austenitic stainless steel after plasma nitriding. Surface and Coatings Technology. 2000; 133-134:259-263. http://dx.doi.org/10.1016/ S0257-8972(00)00930-0

4. Li CX and Bell T. Corrosion properties of active screen plasma nitrided 316 austenitic stainless steel. Corrosion Science. 2004; 46:1527-1547. http://dx.doi.org/10.1016/j. corsci.2003.09.015

5. Sousa RRM, Araujo FO,Barbosa JCP, Ribeiro KJB, Costa JAP and Alves JR. Nitriding using cathodic cage technique of austenitic stainless steel AISI 316 with addition of $\mathrm{CH}_{4}$ Materials Science and Engineering A. 2008; 487:124-127. http://dx.doi.org/10.1016/j.msea.2007.10.001

6. Sun Y and Huraman E. Effect of carbon addition on lowtemperature plasma nitriding characteristics of austenitic stainless steel. Vacuum. 2006; 81:114-119. http://dx.doi. org/10.1016/j.vacuum.2006.03.003

7. Borges CFM, Hennecke S and Pfender E. Decreasing chromium precipitation in AISI 304 stainless steel during the plasma-nitriding process. Surface and Coatings Technology. 2000; 123:112-121. http://dx.doi.org/10.1016/ S0257-8972(99)00506-X

8. Aksoy M, Kuzucu V, Korkut MH and Yilderim MM. The effect of niobium and homogenization on the wear resistance and some mechanical properties of ferritic stainless steel containing 17-18 wt.\% chromium. Journal of Materials Processing Technology. 1999; 91:172-177. http://dx.doi. org/10.1016/S0924-0136(98)00446-4 reduces the formation of carbides and inhibits chromium nitride precipitation, increasing the material's corrosion resistance. The increase in hardness may be due to the decrease in chromium nitride precipitation and the resulting stabilization of expanded ferrite.

9. Blawert C, Weisheit A, Mordike BL and Knoop FM. Plasma immersion ion implantation of stainless steel: austenitic stainless steel in comparison to austenitic-ferritic stainless steel. Surface and Coatings Technology. 1996; 85:15-27. http:// dx.doi.org/10.1016/0257-8972(96)02880-0

10. Moustafa IM, Moustafa MA and Nofal AA. Carbide formation mechanism during solidification and annealing of $17 \% \mathrm{Cr}$ ferritic steel. Materials Letters. 2000; 42:371-379. http://dx.doi. org/10.1016/S0167-577X(99)00213-X

11. Oliveira AM. Nitretação e carbonitretação por plasma em aços inoxidáveis e influências nas resistências à corrosão e ao desgaste. [Tese]. São Carlos: Instituto de Física de São Carlos, Universidade de São Paulo; 2005.

12. Dillon CP. Corrosion Technology: corrosion resistance stainless steels. New York: Marcel Dekker, Inc.; 1995. p. 1-359.

13. Alves Junior C, Araújo FO, Ribeiro KJB, Costa JAP, Sousa RRM and De Sousa RS. Use of cathodic cage in plasma nitriding. Surface and Coatings Technology. 2006; 201:2450245. http://dx.doi.org/10.1016/j.surfcoat.2006.04.014

14. Sousa RRM, Araujo FO, Ribeiro KJB, Mendes MWD, Costa JAP and Alves JR. Cathodic cage of samples with different dimensions. Materials Science and Engineering A. 2007; 465:223-227. http://dx.doi.org/10.1016/j. msea.2007.03.007

15. Sousa RRM, Araujo FO, Ribeiro KJB, Dumelow T, Costa JAP and Alves JR. Ionic nitriding in cathodic cage of AISI 420 martensitic stainless steel. Surface Engineering. 2008; 24(1):5256. http://dx.doi.org/10.1179/174329408X271589

16. Thaiwatthana S, Li XY, Dong H. and Bell T. Comparison studies on properties of nitrogen and carbon "S" phase on low temperature plasma alloyed AISI 316 stainless steel. Surface Engineering. 2002; 18(6):433-437.

17. Abd El-Rahman AM, El-Hossary FM, Fitz T, Negm NZ, Prokert F, Pham MT et al. Effect of $\mathrm{N}_{2}$ to $\mathrm{C}_{2} \mathrm{H}_{2}$ ratio on r. f. plasma surface treatment of austenitic stainless steel. Surface and Coatings Technology. 2004; 183:268-274. http://dx.doi. org/10.1016/j.surfcoat.2003.09.057 